\title{
Clinical and Epidemiological Profile of Cirrhotic Patients at a Reference Center in Belém-PA, Analysis of 10 years
}

\begin{abstract}
Esther Castello Branco Mello Miranda1, Fernanda Araújo Santos ${ }^{1}$, Ana Rachel Koury Marinho', Mayara Castello Branco de Mello Dias", Suzana Maria Klautau Ferreira1, Renan Dos Santos Cortinhas', Giordana Pereira De Sousa1, Francisco De Almeida Teixeira Neto', Vivianne De Paula Reis Guimarães ${ }^{1}$, Igor Nascimento Batista1, Caio Nogueira Oliveira1, Priscila Nathyelly Dos Santos Graim", Anderson Phelipe Dias Sabry Azar ${ }^{1}$, Alvaro Alves Dos Santos Neto ${ }^{1}$
\end{abstract}

\section{Abstract}

Background: The aim of this study was to analyze the demographic, ethyological and clinical aspects of patients with liver cirrhosis treated in the Chronic Liver Disease Center.

Methods: A descriptive, cross-sectional and retrospective study based on the analysis of 580 pacients' medical records with the diagnosis of hepatic cirrhosis treated from 2004 to 2014 in Belém, Brazil.

Conclusions: The profile was predominantly of male patients, aged between 51 and 60 years, coming from the capital Belem, whose main etiologies of cirrhosis were $C$ hepatitis and alcohol. Ascites was the most frequent clinical manifestation and Child-Pugh score A was the most prevalent.
1 Universidade do Estado do Pará. Belém, Pará, Brazil. Travessa Perebebuí, n²623, Belém. 66095-450 (Brazil).

Contact information:

Fernanda Araújo Santos.

Address: Universidade do Estado do Pará. Travessa Perebebuí, n²623, Belém. 66095-450 (Brazil).

”- fernandaaraujosantos@yahoo.com.b 


\section{Introduction}

The liver plays a central role in the control of the human body [1]. The main histopathological characteristic of liver injury is the deposition of extensive fibrosis with reduced liver function. Cirrhosis is the end result of fibrosis and, once present, the process is irreversible and predisposes to a high risk of mortality [2].

The severity of liver disease is directly related to the extent of fibrosis, which determines the degree of stiffness of the liver. This degree varies according to the etiology of the disease, being the main ones: alcoholic, post-viral hepatitis, secondary to steatohepatitis [3].

Viral ethyologies are caused by hepatitis B, C and $D$ virus infection. Alcoholic liver disease and hepatitis $C$ are the most frequent causes of cirrhosis in developed countries of the West. In Asia and Africa, virus $B$ is the main etiology of the disease. In addition, studies show that up to almost half of patients with cirrhosis are asymptomatic, making it difficult to diagnose early and determine the exact prevalence of the disease. In these, cirrhosis may be discovered during routine exams or at necropsy. However, once the symptoms manifest themselves, the prognosis is severe and the economic costs are high [4].

Hepatic cirrhosis accounts for a high morbidity and mortality rate, both in Brazil and worldwide [5]. According to the World Health Organization, the disease is among the top 10 causes of death in adult individuals worldwide [6].It is important to emphasize the early diagnosis of chronic liver diseases, so that immediate and appropriate treatment is adopted, reducing the risk of progression to cirrhosis and later, for hepatocellular carcinoma, besides contributing to the reduction of the continuous transmission of infection in the liver. cases of viral hepatitis [7].

The aim of this study was to analyze the demographic, ethyological and clinical aspects of patients with liver cirrhosis treated in the Chronic Liver Disease Center.

\section{Methods}

The sample was composed by patients attended at Chronic Liver Disease Center, in Belem (Brazil), from both genders, whose complementary exams (laboratory, endoscopic, and/or ultrasonographic) were suggestive of cirrhosis, in the presence or absence of signs and symptoms of hepatic insufficiency or portal hypertension or histopathological examination of cirrhosis. The clinical diagnosis of cirrhosis was based on signs of portal hypertension (clinical or ultrasonographic) or hepatic insufficiency. A descriptive, cross-sectional and retrospective study included data collected from patients diagnosed with cirrhosis attended in the center between January 2004 and August 2014. Medical records of 580 patients were evaluated. The selected patients signed a Informed Consent Term and were submitted to clinical, epidemiological and histopathological evaluation with specific protocol.

\section{Results}

The search results are distributed in the following eight tables.

\section{Discussion}

In this research, $62 \%$ of the patients were male, which is justified by a greater exposure of men to most risk factors $[8,9]$ and also because men attend less health services, thus, the evolution of undiagnosed fibrosis favors liver cirrhosis [10].

Age over 40 years old is a risk factor for fibrosis evolution [11]. In this study, 33\% of the patients were between 51-60 years old. The advanced age in cirrhotic patients is justified by the slow progression of the disease in viral hepatitis, especially by hepatitis $\mathrm{C}$ virus (HCV) [12].

More than $70 \%$ of the patients come from urban areas. This suggests the possibility of under-reporting of liver disease in rural areas, due to the lack of medical care in the country. In addition, this disease 
Table 1. Gender of cirrhotic patients attended at Chronic Liver Disease Center between 2004 e 2014.

\begin{tabular}{|l|c|c|}
\hline \multicolumn{1}{|c|}{ Gender } & N & $\%$ \\
\hline Female & 218 & 38 \\
\hline Male & 362 & 62 \\
\hline Total & 580 & 100 \\
\hline & Source: research protocol. \\
\hline
\end{tabular}

Table 2. Age of cirrhotic patients attended at Chronic Liver Disease Center between 2004 e 2014.

\begin{tabular}{|c|c|c|}
\hline Age & $\mathbf{N}$ & $\%$ \\
\hline $0-10$ & 5 & 1 \\
\hline $11-20$ & 9 & 2 \\
\hline $21-30$ & 12 & 3 \\
\hline $31-40$ & 34 & 8 \\
\hline $41-50$ & 73 & 17 \\
\hline $51-60$ & 141 & 33 \\
\hline $61-70$ & 96 & 22 \\
\hline $71-80$ & 41 & 10 \\
\hline$>80$ & 16 & 4 \\
\hline Total & 427 & 100 \\
\hline
\end{tabular}

Table 3. Hometown region in state of Pará (Brazil) of cirrhotic patients attended at Chronic Liver Disease Center between 2004 e 2014.

\begin{tabular}{|l|c|c|}
\hline Hometown region in state of Pará & N & $\%$ \\
\hline Belem & 278 & 73 \\
\hline North East & 58 & 15 \\
\hline South East & 23 & 6 \\
\hline Marajó & 8 & 2 \\
\hline Baixo Amazonas & 7 & 2 \\
\hline South West & 4 & 1 \\
\hline Others & 4 & 1 \\
\hline Total & 382 & 100 \\
\hline
\end{tabular}

Source: research protocol.
Table 4. Ethyology related to cirrhotic patients attended at Chronic Liver Disease Center between 2004 e 2014.

\begin{tabular}{|l|c|c|}
\hline \multicolumn{1}{|c|}{ Ethyology } & N & $\%$ \\
\hline Alcohol & 196 & 43 \\
\hline HCV & 139 & 31 \\
\hline HBV & 56 & 12 \\
\hline Autoimmune & 17 & 4 \\
\hline Idiopathic & 15 & 3 \\
\hline Biliary & 14 & 3 \\
\hline NASH & 9 & 2 \\
\hline Others & 10 & 2 \\
\hline Total & 456 & 100 \\
\hline
\end{tabular}

Table 5. Clinical manifestations of cirrhotic patients attended at Chronic Liver Disease Center between 2004 e 2014.

\begin{tabular}{|l|c|c|}
\hline \multicolumn{1}{|c|}{ Clinical manifestations } & N & $\%$ \\
\hline Ascites & 215 & 37 \\
\hline Edema & 186 & 32 \\
\hline Abdominal pain & 163 & 28 \\
\hline Jaundice & 139 & 24 \\
\hline Gastrointestinal disorder & 135 & 23 \\
\hline Weight loss & 105 & 18 \\
\hline Hemorrhagy & 89 & 15 \\
\hline Fever & 84 & 14 \\
\hline Spenomegaly & 76 & 13 \\
\hline Paleness & 76 & 13 \\
\hline Encephalopathy & 74 & 13 \\
\hline Telangiectasia & 51 & 9 \\
\hline Hepatomegaly & 39 & 7 \\
\hline Palmar erythema & 37 & 6 \\
\hline Choluria & 25 & 4 \\
\hline Collateral circulation & 24 & 4 \\
\hline Pruritus & 19 & 3 \\
\hline
\end{tabular}


Table 6. Upper digestive endoscopy of cirrhotic patients attended at Chronic Liver Disease Center between 2004 e 2014.

\begin{tabular}{|l|c|c|}
\hline \multicolumn{1}{|c|}{ Upper digestive endoscopy } & N & $\%$ \\
\hline Absence of esophageal varices & 42 & 17 \\
\hline Presence of esophageal varices & 205 & 83 \\
\hline Total & 247 & 100 \\
\hline & Source: research protocol. \\
\hline
\end{tabular}

Table 7. Anti-HIVof cirrhotic patients attended at Chronic Liver Disease Center between 2004 e 2014.

\begin{tabular}{|c|c|c|}
\hline ANTI-HIV & $\mathbf{N}$ & $\%$ \\
\hline Positive & 5 & 11 \\
\hline Negative & 46 & 89 \\
\hline Total & 51 & 100 \\
\hline
\end{tabular}

Table 8. Child-Pugh score of cirrhotic patients attended at Chronic Liver Disease Center between 2004 e 2014.

\begin{tabular}{|c|c|c|}
\hline Child-Pugh score & $\mathbf{N}$ & $\%$ \\
\hline$A$ & 35 & 42 \\
\hline B & 28 & 34 \\
\hline C & 20 & 24 \\
\hline \multirow[t]{2}{*}{ Total } & 83 & 100 \\
\hline & rese & rotocc \\
\hline
\end{tabular}

has a urban pattern of infection, where there is a greater exposure to risk factors [12].

The most commom ethyology was alcoholic, followed by $C$ hepatitis, as observed in other studies $[13,14]$. The ingestion of alcohol accelerates the frequency of hepatic decompensation, doubles the risk of mortality in cirrhotic patients, and there is a worsening of prognosis when there is an association with other ethyologies ${ }^{1}$. Meanwhile the natural history of hepatitis C virus includes long asymptomatic periods, which contributes a large number of patients to ignore this problem [15].

There were cases of co-infection between HIV and viral hepatitis. This association is a frequent event, due to the common risk factors in the transmission of these diseases. Viral hepatitis is the leading cause of morbidity and mortality among HIV-infected patients. The progression rate of hepatic fibrosis in co-infected patients is about twice as fast as in patients infected only with B or D virus [16].

The most frequent clinical manifestations were ascites, edema and abdominal pain. Researches have shown that ascites is the main clinical manifestation of cirrhosis decompensation and approximately half of cirrhotic patients will develop ascites within 10 years of follow-up [17]. Ascites occurs due to alterations in the functioning of hepatocytes resulting in decreased albumin synthesis, which reduces plasma oncotic pressure and contributes to the formation of edema [18].

Another important finding was the presence of esophageal varices identified in the vast majority of patients by upper digestive endoscopy. In cirrhosis, portal hypertension leads to the development of esophageal varices, which is a very commom clinical manifestation found in studies with this group of patients [19].

The most frequent Child-Pugh score was A, followed by $B$ and $C$. This result disagrees with other researches in hepatopathy specialized services, which $C$ is the most commom score [14]. The authors believe that due to the successful treatment and follow-up in this center, patients have lower scores.

\section{Conclusion}

The importance of cirrhosis in public health scenario, due to its high morbidity, mortality and scarcity of regional information makes this research a way to contribute to a better understanding of regional aspects of this disease. Thus, it is emphasized the need for new studies that allow a deep analysis of this theme and optimize the quality of care to the population, particularly highlightning aspects related to treatment and prevention. 


\section{Contribution}

Fernanda Santos, Ana Rachel Marinho, Mayara Dias, Giordana Sousa, Francisco Neto, Renan Cortinhas, Vivianne Guimarães, Igor Batista, Caio Oliveira, Priscila Graim, Esther Miranda: review of literature, data collect, interpretation of data, writing and concept of the manuscript

Anderson Azar, Alvaro Neto: review of literature, data collect, interpretation of data, writing and 3 of the manuscript.

\section{Fundings}

The authors declare having had no financial support.

\section{Conflict of interest disclosures}

The authors declare that there are no conflicts of interest in this study.

\section{References}

1. Mattos AA, Dantas-Corrêa EB. Tratado de Hepatologia. 1st ed. Rio de Janeiro: Editora Rubio; 2010.

2. Fattovich G, Giustina G, Degos F, et al. Effectiveness of interferon alfa on incidence of hepatocellular carcinoma and decompensation in cirrhosis type C. European concerted action on viral hepatitis. J Hepatol. 1997; 27(1):201-5.

3. Nguyen-khac E. et al. Alcohol Clin Exp Res. 2010 Jul; 34(7):114653.

4. Manock SR et al. An outbreak of eminent hepatitis delta in the Woarani, an indigenous people of Amazon basin of Ecuardo. Am. J. Trop. Med. Hyg. 2000; 63(3,4): 209-13.

5. Maeda MFY, Silva CD, Harima LS, Silva LFF, Ctenas B, Alves VAF. Vascularização na cirrose hepática: estudo imunoistoquímico baseado em necropsias. Arq Gastroenterol. 2008 Jan-Mar; 45(1).

6. WHO. World Health Organization. Injuries and violence the facts. Global burden of disease. Switzerland: World Health Organization; 2004.

7. Ferreira CT, Silveira TR. Hepatites virais: aspectos da epidemiologia e da prevenção. Rev. bras. epidemiol. 2004 Dec; 7(4): 473-87

8. Fecury AA. Vírus da Hepatite C: prevalência dos genótipos, fatores de risco, alterações bioquímicas e histopatológicas de pacientes atendidos no Núcleo de Medicina Tropical. 2011. Dissertação de Mestrado. Universidade Federal do Pará - Núcleo de Medicina Tropical.
9. Aquino JA, Pegado KA, Barros LP, Machado LFA. Soroprevalência de infecções por vírus da hepatite $B$ e vírus da hepatite $C$ em indivíduos do Estado do Pará. Rev. Soc. Bras. Med. Trop. 2008 Aug; 41(4): 334-7.

10. Levorato CD, Mello LM, Silva AS, Nunes AA. Fatores associados à procura por serviços de saúde numa perspectiva relacional de gênero. Ciênc. saúde coletiva. 2014 Apr; 19(4): 1263-74.

11. Brasil. Ministério da Saúde. Secretaria de Vigilância em Saúde. Protocolo clínico e diretrizes terapêuticas para hepatite viral C e coinfecções. 1st ed. Brasília: Ministério da Saúde; 2011.

12. Miranda ECBMM. Estudo clínico, laboratorial e histopatológico de grupos selecionados de pacientes com hepatite $C$ crônica em Belém - Pará. 2008. Tese de Doutorado. Instituto Oswaldo Cruz.

13. Conte VP. Hepatite crônica por vírus - Parte 1 Considerações gerais. Arq. Gastro. Enterol. 2000; 37(3):187-94.

14. Poffo MR, Sakae TM, Mota A, Souza AR. Perfil epidemiológico e fatores prognósticos de mortalidade intrahospitalar de pacientes cirróticos internados no Hospital Nossa Senhora da Conceição. Arquivos Catarinenses de Medicina. 2009; 38(3):78-85.

15. Silva AS, Santos LL, Passos ADC, Sankarankutty AK, Martinelli ALC, Castro e Silva O. Chronic liver disease prevention strategies and liver transplantation. Acta Cir. Bras. 2006; 21(Suppl 1):7984.

16. Pace $F H$, Ferreira $L E$, Silva $A E$, Ferraz ML. Liver fibrosis progression in HIV/hepatitis $C$ virus coinfected patients with normal aminotransferases levels. Rev. Soc. Bras. Med. Trop. 2012; 45(4):444-7.

17. Arroyo V, Colmonero J. Ascites and hepatorenal syndrome in cirrhosis: pathophysiological basis of therapy and current management. J. Hepatol. 2003; 38(Suppl 1):S69-S89.

18. Coelho EB. Mecanismos de formação de edemas. Medicina. 2004; 37(3/4):189-98.

19. Schechter RB, Lemme EMO, Coelho HSM. Gastroesophageal reflux in cirrhotic patients with esophageal varices without endoscopic treatment. Arq Gastroenterol. 2007; 44(2):145-50.
Publish in International Archives of Medicine

International Archives of Medicine is an open access journal publishing articles encompassing all aspects of medical science and clinical practice. IAM is considered a megajournal with independent sections on all areas of medicine. IAM is a really international journal with authors and board members from all around the world. The journal is widely indexed and classified Q2 in category Medicine. 